\title{
FREQUENCY OF HLA-DRB1/DQB1 ALLELES AMONG TYPE 1 DIABETES PATIENTS IN DUHOK, KURDISTAN REGION (IRAQ)
}

\author{
DHIA J. AL-TIMIMI1, BSC (Pharm), MPhil, PhD* \\ SALMA S. SHAFEEQ, MBChB, MSc** \\ IDRIS H. AHMED, MBChB, MD*** \\ RAWAND A.AL-QADI, BSC, MSc**
}

Submitted 04/09/2018; accepted 03/03/2019

\begin{abstract}
Background: A large number of studies have demonstrated that specific alleles at the HLADRB1 andHLA- DQB1 loci are strongly associated with type 1 diabetes mellitus (T1DM). This preliminary study investigated the heterogeneity in HLA class 11 genotypes distribution among Kurd patients with type 1 diabetes.

Patients and Methods: The study was conducted at Duhok Diabetes Center, Duhok, Kurdistan Region (Iraq). The study participants comprised 96 unrelated T1DM patients and 48 healthy control subjects. Currently, HLA typing methods are relatively expensive and time consuming. We sought to determine the minimum number of HLA polymorphism among T1DM patients and healthy controls that could define the HLA-DR/DQ alleles relevant to T1DM patients .All participants were typed at a polymerase chain reaction-(PCR) for theDRB1 and DQB1 loci. The association analysis was performed by comparing the frequency of DR/DQ alleles among the diabetic patients with the frequency of alleles in the healthy controls.

Results: Number of specific DR/DQ alleles has been identified and a statistically significant association with diabetes has been established. Compared with the healthy controls, patients were more than two-third as likely to have HLA- DRB1*03and -DRB1*04. HLADQB1*02allele was also more frequent in T1DM patients. HLA-DRB1*01,-DQB1*05 and DQB1*06 were less frequent in T1DM patients.

Conclusions: The data indicate that the HLA-DRB $1 * 03$, -DRB $1 * 04$ and -DQB1*02 were positively associated with TID and may be the most prone alleles, while the HLA-DRB $1 * 01$ followed by-DQB1*05 and -DQB1*06 were negatively associated with TID and may be the most protective alleles.
\end{abstract}

Duhok Med J 2019; 13 (1):66-73.

Keywords: HLA-DR/DQ Alleles, Type 1 Diabetes Mellitus, Kurd Population.

There is increasing evidence on the leukocyte antigen (HLA) class 11 genes and type 1 diabetes mellitus ${ }^{1}$. Subsequent analysis on HLA region shows that HLADRB1/DQB1 genes have the strongest association with T1DM, and susceptible alleles and genotypes are implicated in the pathogenesis of the disease ${ }^{2}$. These genotypes are transmitted in more than $80 \%$ of affected siblings ${ }^{3}$. Despite evidence suggestive of possible widespread family aggregation in Kurd population $^{4,5}$, attempts to investigate the

\footnotetext{
* Professor., Department of Medical Chemistry, College of Medicine, University of Duhok, Kurdistan Region, Iraq.

** Teaching Laboratories, Duhok, Kurdistan Region, Iraq.

***Duhok Diabetes Center, Azadi Teaching Hospital, Duhok, Kurdistan Region, Iraq.

Correspondence author to: Dhia J.Al-Timimi, altmimidj@yahoo.com, Mobil +9647504228908
} 
heterogeneity in HLA class 11 genotypes in T1DM patients have been few ${ }^{6}$.Thus, this preliminary study was aimed to examine the frequency distributionof HLA-DR/DQ genotypes and alleles in a sample of T1DM patients in comparison with those of healthycontrols and to ascertain the relationship betweenHLADRB1/DQB1 genes and the risk of diabetes among Kurd population.

\section{MATERIALS AND METHODS}

The study was carried out between September 2014 and April 2015 at Duhok Diabetes Center, Duhok, Kurdistan Region (Iraq).The subjects enrolled in this study (April 2015 data freeze) comprise 96 T1DM patients (42 males and 54females, mean age $13.3+3.6 \mathrm{yr}$ ), diagnosis was according to clinical features and laboratory findings. The means of height and weight were used to calculate the body mass index (BMI).All T1DM patients were receiving insulin for controlling hyperglycemia, were not obese (body mass index $19.5+3.5 \mathrm{~kg} / \mathrm{m}$ ), were free of any concomitant complication, and were not receiving additional treatment at the time blood collection. Controls consisted of secondary school students and comprised 48 apparently healthy subjects (12 males and 36 females, mean age $12.6+3.5 \mathrm{yr}$ ). Control subjects had normal fasting/random glucose levels and no family history of T1DM or other autoimmunediseases'. Allparticipants (patients and controls) were Kurdish ethnicity, and an informed consent was obtained from all of them.

The genomic deoxyribonucleic acid (DNA) extraction was done for all subjects by using deoxyribonucleic acid isolation Kit (QIAampDNA Blood Mini Kit). The HLA-DRB1 and-DQB1 gene alleles were analyzed with the polymerase chain reaction-(PCR) sequence-specific priming technique with the SSP HLA DQB-DRB Combi tray genotyping Kit (Lot No. 78V) according to the manufacture specifications(Olerup SSP AB, Stockholm, Sweden).. PCR products were analyzed on $2 \%$ agarose gel.

Data were collected and analyzed using SPSS (Statistical Package for Social Science) software, version 17.0(SOSS, Chicago; Illinois, USA).

\section{RESULTS}

The descriptive characteristics of the study subjects are shown in Table 1.The patient group was age, sex and body mass index (BMI) matched with the healthy control group. The frequency distribution of HLADRB1/DQB1 alleles among the patients and the healthy controlsis shown in Table2.

Table 1- Descriptive Characteristics of the Study Subjects

\begin{tabular}{|c|c|c|c|}
\hline Characteristic & Patients & Controls & $P$-value \\
\hline $\mathbf{N}$ & 96 & 48 & \\
\hline Age (years) & $13.3 \pm 3.6$ & $12.6+3.5$ & 0.12 \\
\hline Male sex, n (\%) & $42(4 \overline{3} .7)$ & $12(\overline{25.0})$ & 0.07 \\
\hline $\mathrm{BMI}\left(\mathrm{Kg} / \mathrm{m}^{2}\right)$ & $19.5 \pm 3.6$ & $\mathbf{1 7 . 8} \pm \mathbf{3 7}$ & 0.07 \\
\hline Positive family history of T1DM,n(\%) & $36(3 \overline{7} .5)$ & -- & - \\
\hline FBS $(\mathrm{mg} / \mathrm{dl})$ & $227.7 \pm 3.3$ & $86.5 \pm 4.7$ & 0.001 \\
\hline HbA1c\% & $10.2 \pm 2.4$ & $4.8 \pm 0.4$ & 0.001 \\
\hline
\end{tabular}




\begin{tabular}{|c|c|c|c|c|c|c|c|}
\hline \multicolumn{6}{|c|}{ Duhok Medical Journal } & \multicolumn{2}{|c|}{ Volume 13, Issue 1, 2019} \\
\hline \multicolumn{8}{|c|}{ Table 2- Frequency of DRB1-DQB1Alleles in TID Patients and Healthy Controls } \\
\hline \multirow[t]{2}{*}{ HLA Genotype } & \multicolumn{2}{|c|}{ T1DM Patients } & \multicolumn{2}{|c|}{ Controls } & \multirow[b]{2}{*}{$\mathbf{O R}$} & \multirow[b]{2}{*}{$95 \% \mathrm{Cl}$} & \multirow[b]{2}{*}{$P$-value } \\
\hline & $\begin{array}{c}\text { No. of alleles } \\
192\end{array}$ & F $(\%)$ & $\begin{array}{c}\text { No. of alleles } \\
96\end{array}$ & s F (\%) & & & \\
\hline \multicolumn{8}{|l|}{ HLA-DRBI } \\
\hline$* 01$ & 6 & (3.1) & 12 & (12.5) & 0.22 & 0.06-0.82 & 0.015 \\
\hline$* 03$ & 64 & (33.3) & 16 & (16.7) & 2.5 & $1.26-4.95$ & 0.007 \\
\hline$* 04$ & 72 & (37.5) & 14 & (14.6) & 3.5 & $1.74-7.08$ & 0.002 \\
\hline$* 07$ & 8 & (4.2) & 4 & (4.2) & 1.0 & $0.24-4.11$ & 1 \\
\hline$* 08$ & 2 & (1.0) & 5 & $(5.2)$ & 0.19 & $0.02-1.67$ & 0.211 \\
\hline$* 09$ & $\mathbf{0}$ & $(0.0)$ & $\mathbf{0}$ & $(0.0)$ & - & - & - \\
\hline$* 10$ & 4 & (2.1) & 7 & (7.3) & 0.27 & $0.05-133$ & 0.169 \\
\hline$* 11$ & 20 & (10.4) & 17 & (17.7) & 0.54 & $0.23-1.25$ & 0.146 \\
\hline$* 12$ & $\mathbf{0}$ & (0.0) & $\mathbf{0}$ & (0.0) & - & - & - \\
\hline$* 13$ & 8 & (4.2) & 10 & (10.4) & 0.37 & 0.11-1.23 & 0.095 \\
\hline$* 14$ & 0 & $(0.0)$ & 4 & (4.2) & - & - & - \\
\hline$* 15$ & 8 & (4.2) & 7 & (7.3) & 0.55 & 0.15-1.95 & 0.351 \\
\hline$* 16$ & $\mathbf{0}$ & $(0.0)$ & 0 & (0.0) & - & - & - \\
\hline \multicolumn{8}{|l|}{ HLA-DQB1 } \\
\hline$* 0280$ & (41.6) & 13 (13.6) & 4.56 & $2.23-9.29$ & 0.0004 & & \\
\hline$* 03$ & 84 & (43.7) & 34 & $(35.5)$ & 1.41 & $0.79-2.53$ & 0.238 \\
\hline$* 04$ & 4 & (2.0) & 2 & (2.0) & 1.0 & 0.13-7.24 & 1.0 \\
\hline$* 05$ & 12 & $(6.2)$ & 26 & (27) & 0.17 & $0.07-0.45$ & 0.001 \\
\hline$* 06$ & 12 & (6.2) & 21 & (21.9) & 0.23 & $0.09-0.62$ & 0.003 \\
\hline
\end{tabular}

Significant DRB1-DQB1 genotype differences were seen between T1DM patients and controls, 6 of 20 alleles being significantly different $(\mathrm{P}<0.05)$.Compared with controls, the most frequent allele of the HLA-DRB1 genotype among patients

Table 3: Frequency of DRB1-DQB1Alleles in TID Patients according to Parents History of Type 1 Diabetes.

$\begin{array}{lc}\text { HLA Genotype } & \text { parents history of TID } \\ \text { Positive }(n=36) & \text { Negative }(n=60)\end{array}$

\begin{tabular}{|c|c|c|c|c|c|c|c|}
\hline & $\begin{array}{c}\text { No. of alleles } \\
72\end{array}$ & $\mathbf{F}(\%)$ & $\begin{array}{l}\text { No. of alleles } \\
120\end{array}$ & $\mathbf{F}(\%)$ & OR & $95 \% \mathrm{Cl}$ & $P$-value \\
\hline \multicolumn{8}{|c|}{ HLA-DRBI } \\
\hline$* 01$ & 0 & $(0.0)$ & 6 & $(5.0)$ & - & - & - \\
\hline$* 03$ & 22 & (30.5) & 42 & (35.0) & 0.81 & 0.33-1.1.98 & 0.654 \\
\hline$* 04$ & 28 & (38.8) & 44 & (36.6) & 1.10 & $0.46-2.57$ & 0.827 \\
\hline$* 07$ & 2 & $(2.7)$ & 6 & $(5.0)$ & 0.54 & $0.05-5.42$ & 1.000 \\
\hline$* 08$ & 2 & (2.7) & $\mathbf{0}$ & - & - & - & - \\
\hline$* 09$ & 0 & $(0.0)$ & $\mathbf{0}$ & $(0.0)$ & - & - & - \\
\hline$* 10$ & $\mathbf{0}$ & $(\mathbf{0 . 0})$ & 4 & (3.3) & - & - & - \\
\hline$* 11$ & 8 & (11.1) & 12 & (10.0) & 1.10 & $0.29-4.29$ & 1.000 \\
\hline$* 12$ & $\mathbf{0}$ & $(\mathbf{0 . 0})$ & $\mathbf{0}$ & $(\mathbf{0 . 0})$ & - & - & - \\
\hline$* 13$ & 6 & (8.3) & 2 & (1.6) & 5.36 & 0.53-53.7 & 0.293 \\
\hline$* 14$ & 0 & (0.0) & $\mathbf{0}$ & $(0.0)$ & - & - & - \\
\hline * 15 & 4 & (5.5) & 4 & (3.3) & 1.7 & $0.22-12.6$ & 0.964 \\
\hline$* 16$ & $\mathbf{0}$ & $(\mathbf{0 . 0})$ & $\mathbf{0}$ & $(0.0)$ & - & - & - \\
\hline \multicolumn{8}{|c|}{ HLA-DQB1 } \\
\hline$* 02$ & 24 & (33.3) & 56 & (46.6) & 0.57 & $0.24-1.34$ & 0.199 \\
\hline *03 & 38 & (52.7) & 46 & (38.3) & 1.79 & $0.77-4.14$ & 0.167 \\
\hline$* 04$ & 4 & $(5.5)$ & 0 & $(\mathbf{0 . 0})$ & - & - & - \\
\hline$* 05$ & $\mathbf{0}$ & $(0.0)$ & 0 & $(0.0)$ & - & - & - \\
\hline$* 06$ & 6 & (8.3) & 6 & (5.0) & 1.72 & $0.32-9.5$ & 0.805 \\
\hline
\end{tabular}


was DRB1*03and DRB1*04, (OR 2.5, $95 \% \mathrm{Cl} 1.26-4.95, p=0.007)$ and $(\mathrm{OR} 3.5$, 95\%CL 1.74-7.08, $p=0.002)$ respectively. HLA- DQB $1 * 02$ allele was also more frequent in T1DM patients (OR 4.56, $95 \% \mathrm{Cl}$ 2.23-9.29, $p=0.0004)$. HLADRB $1 * 01, \mathrm{DQB} 1 * 05$ and DQB $1 * 06$ were less frequent in T1DM patients than they were in healthy controls. In the case of alleles DRB1*9, DRB1*12 and DRB1*16 were unidentified in the study subjects. Comparing the family history risk for the most frequent $\mathrm{DRB} 1 * 03, \quad \mathrm{DRB} 1 * 04$ ,DQB $1 * 02$ alleles with the less frequent alleles $\mathrm{DRB} 1 * 01, \mathrm{DQB} 1 * 05, \mathrm{DQB} 1 * 06$ alleles (OR 0.47), the results are shown in Table 3.

\section{DISCUSSION}

Subsequent analysis on HLA region shows that HLA-DR/DQ genes have the strongest association with type 1 diabetes ${ }^{7}$.The association varies among various ethnic and racial groups ${ }^{8}$.The association analyses presented here show a statistically significant risk hierarchy among the many associated DRB1-DQB1 alleles, ranging from highly positive to highly negative, consistent with results of previous studies ${ }^{9,10}$.For example, the most frequent DRB1*03 and DRB1*04 has an odds ratio of 2.5 and 3.5 while theless frequent DQB1*05 and DQB1*06 has an odd ratio 0.17 and 0.23 respectively.However, comparing the type 1 diabetes risk of DRB1*04-DQB1*05 with the DRB1*04DQB1*06 (OR 1.0) reveals the risk conferred by DRB1 alleles. The comparison also illustrate the importance of both DRB1 and DQB1 alleles inthe family history risk for the most frequent DRB $1 * 03, \quad$ DRB $1 * 04, \mathrm{DQB} 1 * 02$ alleles with the less frequent alleles DRB $1 * 01$, DQB1*05, DQB1*06 alleles (OR 0.47), and reveals the risk is an epistaticinteraction. It was noteworthy that DRB1*04-DQB1*0302 haplotypes in particular conferring strong disease susceptibility among variousethnicities ${ }^{11}$, similar to what was shown here for Kurdpatients. It remains to be seen whether the lack association of HLADR3/4 and DQ*02 with family history of parents in Kurdistan region is directly linked with the generalized lower incidence of T1DM, as was suggested $^{12}$.Type 1 diabetes incidence rates are extremely low in Asian population $^{13}$.For example, in Japanese patients with classic T1DM, DRB1*0505DQB1*0401 and DRB1*0901DQB1*0303 are major susceptible HLADR-DQ haplotypes, whereas DRB1*1502DQB1*0601 and DRB1*1501DQB $1 * 0602$ are protective ${ }^{14}$ While in Iraqi Arab population, DQB $1 * 0101$ and *0201 alleles were found with high frequencies among T1DM patients in comparison with healthy controls ${ }^{15}$. In contrast, the present study suggested that the DRB1*03, DRB1*04 and DQB1*02 alleles were statistically significant frequencies among Kurd T1DM patients. A finding also reported in Iranian ${ }^{16}$, Israeli Jewish $^{17}$, Arabs ${ }^{11}$ and others ${ }^{18}$. However, this is the first study to demonstrate an association between HLA-DR/DQ alleles and an increased risk for diabetes, further research with a larger cohort will be necessary.

In summary, the present study indicated that the specific HLA-DR/DQ alleles, DRB1*03-DRB1*04-DQB1*02 showed the strongest association, and negative 
association ofDRB1*01-DQB1*05-

DQB1*06 alleles with T1DM in Kurd population. This finding may have clinical implications due to increased risk of future diabetes.

\section{ACKNOWLEDGEMENT}

We acknowledge the support of the staff of Duhok Diabetes Center and secondary schools that provided the facilities for the interviews and the records.

\section{REFERENCES}

1. Erlich H, Valdes AM, Noble J, Carlson JA, Varney M, Concannon P, et al. Type 1 Diabetes Genetics Consortium HLA-DR-DQ haplotypes and genotypes and type 1 diabetes risk: analysis of the type 1 diabetes genetics consortium families. Diabetes. 2008; 57:1084-1092.

2. Barker JM, Triolo TM, AlyTA, Baschal EE, Babu SR, Kretowski A, etal.Two single nucleotide polymorphisms identify the highestrisk diabetes HLA genotype: potential for rapid screening. Diabetes. 2008;57:3152-3155.

3. Morahan G. Insights into type 1 diabetes provided by genetic analyses. CurrOpinEndocrinol Diabetes Obes. 2012;19:263-270.

4. Al-Timimi DJ, Mustafa AH. Prevalence of metabolically obese, normal-weight individuals among first degree relatives of patients with type 2 diabetes. JABHS. 2012;13(3):2-8.

5. Al-Timimi DJ, SalehSF.Prevalence and related factors of asymptomatic hyperglycemia among Kurd in
Duhok, Iraq. Duhok Med J. 2009;3(1):73-83.

6. Al-Hassan AA, Mohammad N, AlGhurabiBH,AbdualElah L. HLA Class I and II Genotyping by PCRSSO in patients with type 1 diabetes mellitus. The Iraqi Postgraduate Medical J. 2013;12(4).

7. Nauyen C, Varney MD, Harrison LC, Morahan G. Definition of High-Risk Type 1 Diabetes HLA-DR and HLADQ Types Using Only Three Single Nucleotide Polymorphisms. Diabetes. 2013;62(6):2135-2140.

8. Kawabata Y,IkegamiH,Kawaguchi Y Fujisawa T, Shintani M, Ono M, et al.Asian-specific HLA haplotypes reveal heterogeneity of the contribution of HLA-DR and -DQ haplotypes to susceptibility to type 1 diabetes. Diabetes.2002;51:545-551.

9. Sanjeevi CB, Hook P, Landin-Olsson M, Kockum I, Dahlquist G, Lybrand TP, et al. DR4 subtypes and their molecular properties in a populationbased study of Swedish childhood diabetes. Tissue Antigens. 1996;47:275-283.

10. Aly TA, Ide A, JahromiMM, Barker JM, Fernando MS, Babu SR, et al. Extreme genetic risk for type 1A diabetes. ProcNatlAcadSci USA. 2006; 103:14074-14079.

11. Al-Jenaidi FA, Wakim-Ghorayeb SF, Al-Abbasi A, Arekat MR, IraniHakime N, Najm P, et al.Contribution of selectiveHLADRB1/DQB1 alleles and haplotypes to the genetic susceptibility of type 1 diabetes among Lebanese and Bahraini Arabs. The Journal of 
Clinical Endocrinology and Metabolism. 2005;90(9):5104-5109.

12. Atkinson MA, Eisenbarth GS. Type 1 diabetes:new perspectives on disease pathogenesis and treatment. Lancet. 2001;358:221-229.

13. Park Y,Eisenbarth GS. Genetic susceptibility factors of type 1 diabetes in Asians. Diabetes Metab Res Rev. 2001;7:2-11.

14. Katahira M, Ishingo T, Segawa S, Kuzuya-Nagao K. Hara I. Nishisaki T - Reevaluation of human leucocyte antigen DR-DQ haplotypes and genotype in type 1 diabetes in the Japanese population. Hormone Research. 2008;69:284-289.

15. Mohammad AK, Nadar MI, AlGurabi BH. Genotyping of HLA Class I and Molecules in Type 2 Diabetic Iraqi patients. IOSR journal of Dental and Medical Sciences. 2014;13(4):44-48.

16. Rabbani A, Abbasi F, Taghvaei M, Rabbani B, Moradi B,Shakiba Y, et al. HLA-DRB, ,DQA, and -DQB Allels and haplotypes in Iranian patients with diabetes mellitus type 1 . Pediatr Diabetes. 2013;14(5):366-71.

17. Hirsch D, Narinski R, Klein T, Israel $\mathrm{S}$, Singer . Immunogenetics of HLA class II in Israeli patients with adult-onset type I diabetes mellitus.Hum Immunol. 2007;68:616-622.

18. Honen J, Koeova M, Lipponen K, Sukarova-Angelovska E, Jovanovska A, Knip M. HLA-DR-DQ haplotypes and type 1 diabetes in Macedonia. Hum Immunol. 2009; 70:461-463. 


\section{يوخته}

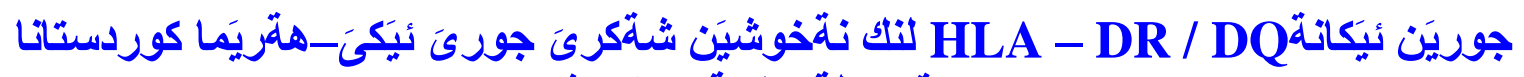

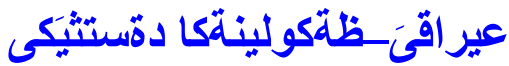

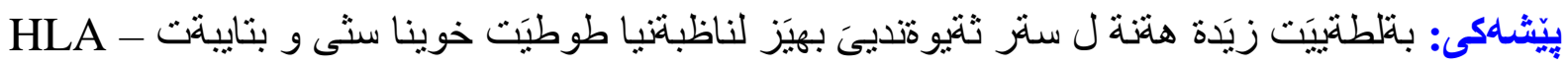

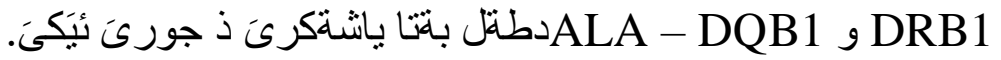

ئارمانج: ل طةريان ل جوازيا جينى ل ALA ذجوريَ دوويَ لناف كورديَن نوش بووى ب شةكرى

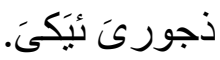

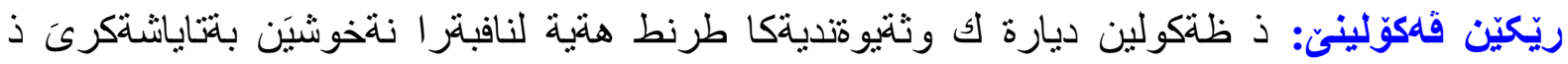

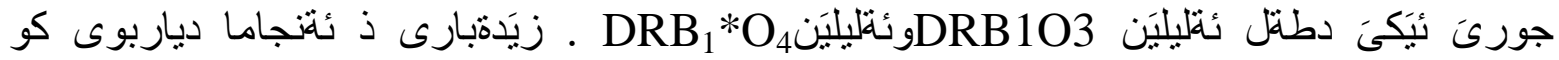

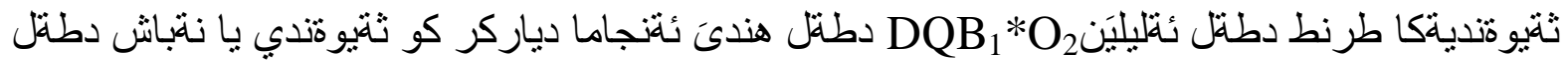

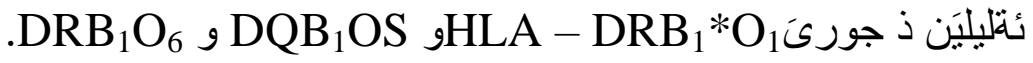

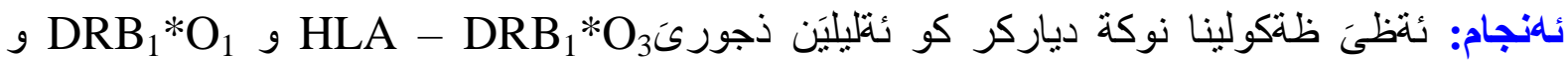

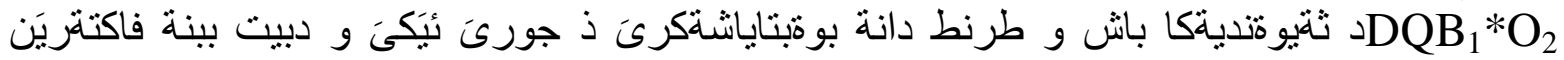

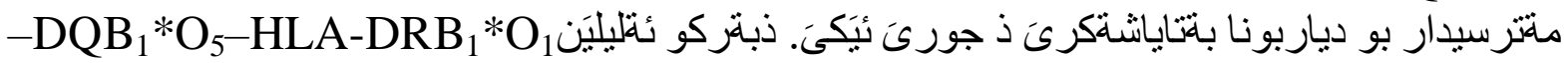

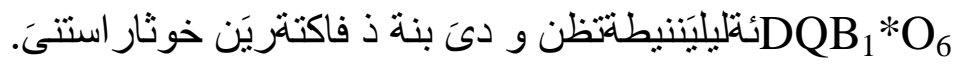




\section{الخلاصة}

الانماط الفردانية HLA - DR / DQ لاى مرضى السكري النوع الاول في اقليم كوردستان العراق دراسة اولية مرية

ALA - و HLA - DRB1 الخلقية والأهداف: هنالك أدلة منزايدة على وجود علاقة قوية بين اليلات خاصة من مع داء السكري النوع الاول. التحري عن الاختلاف الجيني في ALA النوع الثاني ما بين الاكر اد الذين يعانون

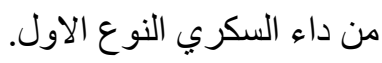

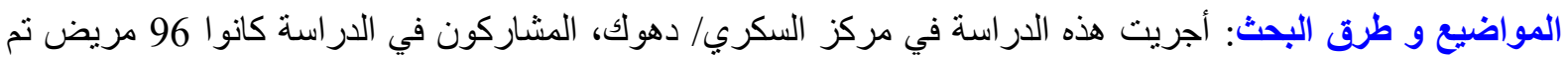

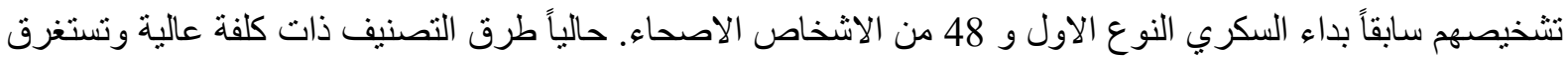

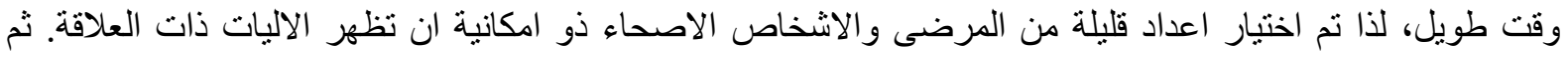
اجريت عملية التصنيف الاليلي لـ (DR/DQ و DRA class) باستخدام مسيار اوليلوثيو كليوتايد الاحادي لتفاعل متسلسلة البلمرة ذو التسلسل الخاص.

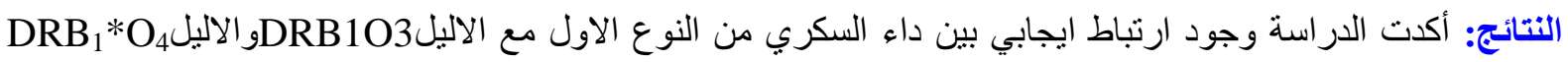
اضافة لذلك بينت النتائج وجود علاقة ايجابية مع الاليل حين اظهرت النتائج علاقة سلبية مع الاليلات

الاستثتاجات: تؤكد الدر اسة الحالية على ان الاليلات ايجابي بداء السكري النوع الاول ويمكن ان تكون عوامل الخطر لقابلية ظهور داء السكري في حين ان الاليلات-HLA DQB ${ }_{1} * \mathrm{O}_{6}-\mathrm{DQB}_{1} * \mathrm{O}_{5}-\mathrm{DRB}_{1} * \mathrm{O}_{1}$ 